\title{
Tokat ili kronik Hepatit B enfeksiyonlu hastalarda Tork Teno virüs ve Hepatit D virüs araştırılması
}

\section{Investigation of Torque Teno virus and Hepatitis D virüs in patients infected with chronic Hepatitis B in Tokat}

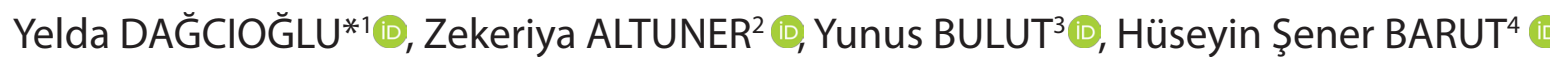

'Gaziosmanpaşa Üniversitesi Araştırma ve Uygulama Hastanesi, Mikrobiyoloji Laboratuvarı,Tokat/TÜRKIYE

${ }^{2}$ Gaziosmanpaşa Üniversitesi, Fen Edebiyat Fakültesi Biyoloji Anabilim Dalı, Tokat/TÜRKIYE

${ }^{3}$ Gaziosmanpaşa Üniversitesi Tıp Fakültesi, Mikrobiyoloji Anabilim Dalı,Tokat/TÜRKiYE

${ }^{4}$ Gaziosmanpaşa Üniversitesi Tıp Fakültesi, Enfeksiyon Hastalıkları Anabilim Dalı, Tokat/TÜRKiYE

\section{Öz}

Amaç: Tokat ilinde kronik hepatit B tanılı hastalarda Hepatit Delta Virüs (HDV) ve Tork Teno Virüs (TTV) araştırması yapıldı.

Gereç ve Yöntemler: Çalışma Ocak 2015-Temmuz 2015 tarihleri arasında Gaziosmanpaşa Üniversitesi Tıp Fakültesi Mikrobiyoloji Anabilim Dalında gerçekleştirildi. Çalışmaya Kronik HBV'li 110 hasta (58'i kadın, 52'si erkek) ve 90 sağlıklı birey dahil edildi. Hasta kanlarından izole edilen TTV-DNA ve HDV-RNA'ların polimeraz zincir reaksiyonları (PZR) yapıldı. Ayrıca hastalarda aspartat aminotransferaz (AST), alanin aminotransferaz (ALT) değerleri de çalışıldı.

Bulgular: Hasta numunelerinin 108'i HDV-RNA negatif, 2'si (\%1,81) HDV-RNA pozitif olarak tespit edildi. Sağlıklı bireylerin tümünde HDV-RNA negatif bulundu. TTV çalışmasında ise 110 numunenin 106'sı (\%96,4) TTV-DNA pozitif olarak bulunurken, 4'ü TTV-DNA negatif olarak tespit edildi. Sağlıklı bireylerde ise 90 numunenin 86'sının (\%95,35) TTV-DNA pozitif, 4'ünün (\%4,65) TTV-DNA negatif olduğu tespit edildi. HDV-RNA pozitif olan hastalarda ALT ve AST değerleri arasında istatiksel olarak anlamlı bir ilişki tespit edilirken $(p<0,05)$, TTV pozitif olan hastalarda ise anlamlı bir ilişki yoktu $(p>0,05)$.

Sonuç: Tokat ilinin, HDV enfeksiyon oranı, Türkiye ortalamasının oldukça altında, dünya genelinde ise, çok düşük endemisite grubuna dahil bölgeler arasında olduğu görüldü. Tokat'ta ilk defa araştırılan TorkTenovirüs ise \%96 oranı ile dünya ve Türkiye ortalamasının oldukça üzerindedir. Kronik hepatit B enfeksiyonlu hasta grubunda araştırılan TorkTenovirüs ve hepatit deltavirüs enfeksiyonları arasında istatistiksel açıdan anlamlı bir ilişki saptanmamıştır.

Anahtar kelimeler: kronik hepatit B; HDV-RNA; TTV-DNA; PCR; prevalans

Sorumlu Yazar*: Yelda Dağcıoğlu, Gaziosmanpaşa Üniversitesi Araştırma ve Uygulama Hastanesi, Mikrobiyoloji Laboratuvarı,Tokat/TÜRKiYE E-posta: yelda.dagcioglu@gop.edu.tr

ORCID: 0000-0001-5169-9702

Gönderim: 25.02.2018 Kabul : 02.06.2018

Doi: $10.18663 /$ tjcl.398474 


\begin{abstract}
Aim: The aim of this study was to investigate the detection, rates and correlations of Torque Teno Virus (TTV) and Hepatitis Delta Virus (HDV) which cause superinfection and coinfection in patients with chronic hepatitis B in Tokat.
\end{abstract}

Material and Methods: A total of 110 patients with chronic HBV infection ( 58 women, 52 men) and 90 healthy subjects were included in the study. Polymerase chain reactions (PCR) of all blood samples were performed with TTV-DNA and HDV-RNA isolations. Aspartate aminotransferase (AST) and alanine aminotransferase (ALT) values of patients were also studied.

Results: 108 samples of the patients were HDV-RNA negative and 2 were (1.81\%) HDV-RNA positive. HDV-RNA were negative in all healthy subjects. In the TTV study, 106 of the 110 samples (96.4\%) were found to be TTV-DNA positive while 4 were found to be TTV-DNA negative. In healthy subjects, 86 of 90 samples (95.35\%) were TTV-DNA positive and 4 (4.65\%) were TTV-DNA negative. A statistically significant relationship was found between ALT and AST values in HDV-RNA positive patients $(p<0.05)$. There was no significant relationship between TTV positive patients $(p>0.05)$.

Conclusion: It has seen that the rate of HDV infection in Tokat province is considerably lower than the average of Turkey and in the World. Torque Teno Virus, which was investigated for the first time in Tokat, is higher than the average of Turkey and World. There was no statistically significant relationship between the infections of Torque Tenovirus and hepatitis deltavirus in patients with chronic hepatitis $B$ infections.

Keywords: chronic hepatitis B; HDV-RNA; TTV-DNA; PCR; prevalance

\section{Giriş}

Dünya genelinde 2 milyar insanın (dünya nüfusunun yaklaşık $1 / 3$ 'ünün) Hepatit B ile enfekte olduğu ve bu kişilerin 400 milyonunda enfeksiyonun kronik Hepatit B hastalığına dönüştüğü bilinmektedir. Hastaların \%75-80'inde herhangi bir belirti vermeksizin gelişir, taramalarda ve kan bağışlarında yapılan tetkiklerde rastlantı sonucu tespit edilebilir [1]. Hepatit B virüsü, akut ve kronik hepatitler, karaciğer sirozu ve hepatosellüler karsinomun başlıca nedenlerindendir.

Hepatit $D$ virüsü ise, Hepatit $B$ virüsü ile birlikte olduğunda enfeksiyona neden olabilen bir defektif virüstür. HBV'nin varlığında vücuda giren virüs, şiddetlienfeksiyonlara sebep olarakani başlayan fulminan hepatit, kanser ve mortaliteye neden olmaktadır[2].

Tork Teno virüs, 1997 yılında Japon bilimadamı Nishizawa tarafından, kan transfüzyon sonrası A-G dışı hepatit gelişen beş hastanın serumunda, klonlama-sekanslama yöntemiyle bir DNA dizisi şeklinde izole edilmiştir.TTV'nin kan tranfüzyonuyla geçtiği düşünülmesi sebebiyle Transfusion Transmitted Virüs olarak da anıldığı yayınlar bulunmaktadır [3].

Bu çalışmada, Tokat ilinde oldukça yoğun olarak gözlenen kronik hepatit $B$ hastalarında süperenfeksiyon ve koenfeksiyona sebep olan HDV ve TTV varlığını tespit etmek amaçlanmıştır.

\section{Gereç ve Yöntemler}

Çalışmaya en az 6 ay süre ile HbsAg ve HBV-DNA kantitatif pozitifliği tespit edilmiş olan 110 kronik Hepatit B hasta kan numunesi ve kontrol grubu olarak da her biri serolojik olarak
HbsAg negatif olarak belirlenen 90 sağlıklı birey kanı olmak üzere 200 numune dahil edildi. Hasta ve kontrol gruplarından alınan $5 \mathrm{ml}$. kandan serumları 15 dakika 3500 RPM'de santrifüj edilerek ayrıldı. HBV-DNA pozitif 110 hastanın 400 $\mu l$ serumunda HDV-RNA ve TTV-DNA izolasyonları, izolasyon cihazı (Magnesia 16 Anatolia Genework, Türkiye) ile yapıldı. Polimeraz zincir reaksiyonları, HDV ve TTV PZR kitlerinin (Anatolia, Bosphore, İstanbul, Türkiye) prosedürüne uygun şekilde PZR cihazında (Montania 483, Anatolia, Türkiye) gerçekleştirildi.

TTV PZR'ı ilk denatürasyon $95^{\circ} \mathrm{C}^{\prime}$ de 14:30 dakika, denatürasyon $95^{\circ} \mathrm{C}$ 'de $00: 30$ dakika, bağlanma $53^{\circ} \mathrm{C}^{\prime}$ de $00: 45$ dakika, sentez $72^{\circ} \mathrm{C}$ 'de 00:45 dakika olmak üzere toplam 45 döngü üzerinden gerçekleştirilmiştir. HDV ise öncelikle reverse transkripsiyon işlemi $50^{\circ} \mathrm{C}$ 'de $30: 00$ dakika yapıldıktan sonra, ilk denatürasyon $95^{\circ} \mathrm{C}$ 'de $14: 30$ dakika, denatürasyon $97^{\circ} \mathrm{C}^{\prime}$ de 00:30 dakika, bağlanma $54^{\circ} \mathrm{C}^{\prime}$ de $01: 20$ dakika, sentez $72^{\circ} \mathrm{C}$ 'de $00: 45$ dakika olmak üzere toplam 50 döngü üzerinden gerçekleştirildi. $22^{\circ} \mathrm{C}^{\prime}$ de 05:00 dakika inkübasyon süresi ve toplam döngü sonrasında PZR işlemi tamamlandı. Amplifikasyon sonrası sonuçların grafikleri ve kantitatif verileri cihazdan elde edildi.

Ayrıca hastaların karaciğer fonksiyon testleri olan AST, ALT, (Roche Cobas INTEGRA/cobas c system, Roche Diagnostic Türkiye ) test kit ve Roche Cobas 501 cihazı kullanılarak çalışıldı.

Çalışma Gaziosmanpaşa Üniversitesi Klinik Araştırmalar Etik Kurulu tarafından Ocak 2015'te 14-KAEK-219 numaralı proje 
olarak onaylanmıştır. Çalışmaya dahil edilen tüm insanlar bilgilendirilmiş onam formunu imzalamıştır.

Çalışmada lineer regresyon ve Spearman's Rho korelasyon testleri yapıldı. Sonuçlarda $p<0,05$ değerleri anlamlı olarak kabul edildi.

\section{Bulgular}

Kronik Hepatit B'Ii 110 hastadan alınan numunelerin 106'sında TTV-DNA pozitif, 4 'ünde ise negatif olarak tespit edilmiştir. TTV taraması yapılan 90 sağlıklı bireyin 86 'sı pozitif ve 4 'ü negatif olarak saptanmıştır (Şekil 1). HDV-RNA çalışmasında ise 110 Kronik Hepatit B'li hasta numunesinin 108'inde HDV-RNA negatif, 2 'sinde ise pozitif olarak $(\% 1,8)$ tespit edilmiştir (Şekil 1,2). Bu iki olgunun da süperinfeksiyon olduğu belirlenmiştir. HDV-RNA düzeyi sağlıklı bireylerde tüm numuneler negatif olarak saptanmıştır.TTV ile HDV arasında herhangi bir ilişki olup olmadığı Spearman'sRho korelasyon testi ile araştııılmıştır. Test sonucunda TTV ile HDV arasında herhangi bir ilişki olmadığına karar verilmiştir $(p>0,05)$ (Tablo 1).

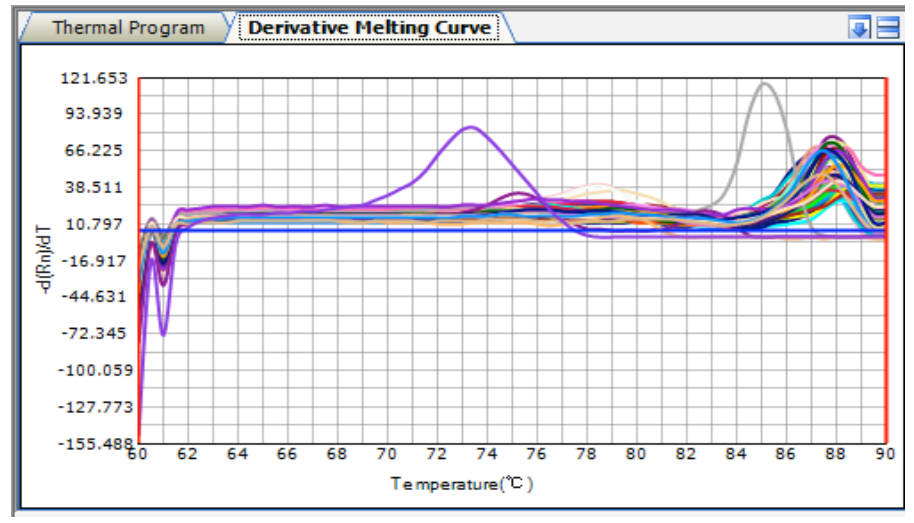

Şekil 1. TTV-DNA çalışma sonuçları

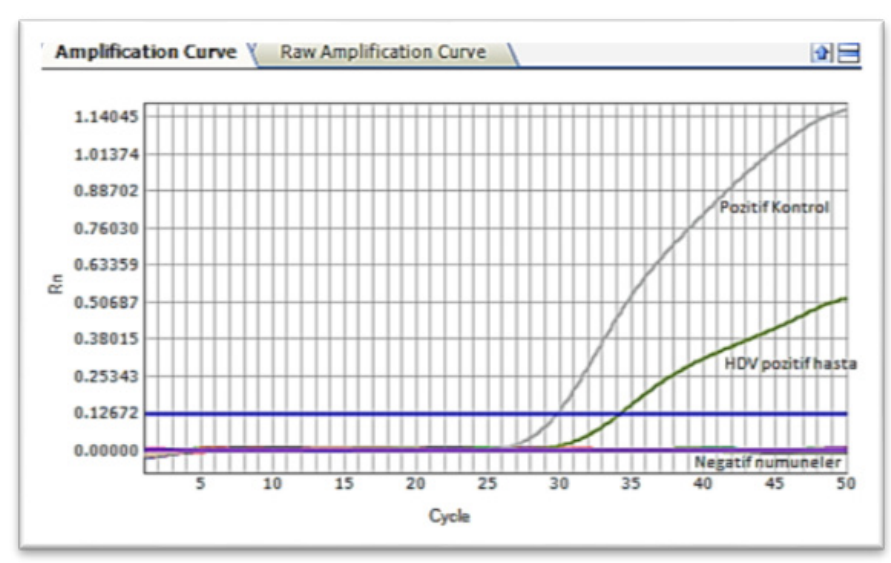

Şekil 2. HDV-RNA çalışma sonuçları

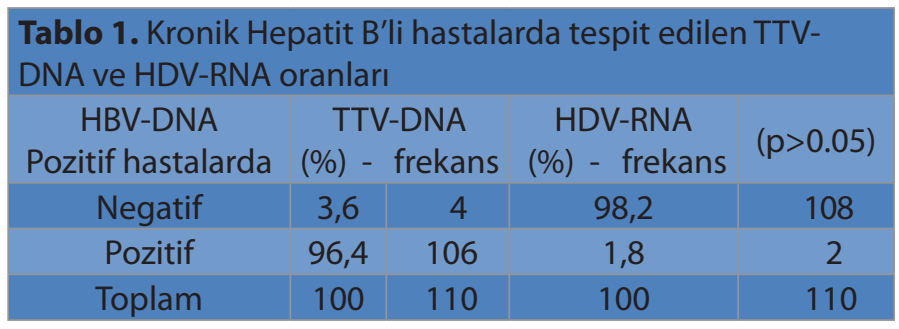

HDV-RNA pozitif olan hastalarda ALT değerleri arasında istatiksel olarak anlamlı bir ilişki tespit edilmiştir $(p<0,05)$. Ayrıca diğer bir karaciğer fonksiyon testi olan AST değerleri ile HDV-RNA pozitif olanlar arasında da anlamlı bir ilişki gözlenmiştir $(p<0,05)$. TTV-DNA pozitif olan hastaların ise karaciğer fonksiyon testleri arasında anlamlı bir ilişki olmadığı ( $p>0,05)$, fakat TTV-DNA pozitif olan hastaların viral yükleri ile yaşları arasında istatiksel olarak anlamlı bir ilişki bulunmuştur $(p<0,05)$ (Tablo 2.).

\begin{tabular}{ll|l|l}
\hline $\begin{array}{l}\text { Tablo 2. HBV-DNA pozitif hastalarda TTV-DNA, HDV-RNA, ALT ve AST parametrelerinin } \\
\text { HBV-DNA(+)lerde }\end{array}$ & TTV-DNA $(+)$ & \multicolumn{1}{c|}{ karşıllaştırılması } \\
& $(n=106)$ & $(n=2)$ & TTV-DNA/HDV-RNA(+) \\
\hline Yaş (ortalama+standart sapma) & $45,25 \pm 14,11(p<0,05)$ & $59,5 \pm 1,5(p>0,05)$ & $59,5 \pm 1,5(p>0,05)$ \\
\hline Kadın & 56 & 2 & 2 \\
\hline Erkek & 50 & 0 & 0 \\
\hline ALT & $28,55 \pm 32,31(p>0,05)$ & $79,8 \pm 59,1(p<0,05)$ & $79,8 \pm 59,1(p<0,05)$ \\
AST & $23,75 \pm 14,64(p>0,05)$ & $58,8 \pm 39,3(p<0,05)$ & $58,8 \pm 39,3(p<0,05)$ \\
\hline
\end{tabular}

\section{Tartışma}

Kronik Hepatit B enfeksiyonu, Hepatit D Virüsünün eklenmesiyle çok daha hızlı ilerleyen, tehlikeli bir forma dönüşebilir. HDV enfeksiyonu genellikle düşük endemisite olarak rastlanılmasına rağmen, HBV enfeksiyonunun sebep olduğu karaciğer hasarını ağırlaştırarak tedavide güçlük ve komplikasyonlara neden olabilmektedir [2].
Yurtdışında yapılan çalışmalarda; Kuzey İtalya'da kronik hepatit B hastalarında \%6,3 anti-HDV pozitif saptanmıştır. Olguların birinin $(\% 0,2)$ serumunda HDAg tespit edilmiştir [4].

İran'da yapılan iki farklı çalışmada; kronik hepatit B hastalarında anti-HDV pozitiflik oranı \%3,5-17,3 olarak bildirilmiştir [5,6]. İran Kan Transfüzyon Organizasyonun yaptığı bir çalışmada 2014 yılı itibariyle HBV pozitif hastaların \%2'sinin HDV enfeksiyonuna sahip olduğu, bu oranın da dünya HDV ortalamasının altında olduğu belirtilmiştir [7]. 
Türkiye'de yapılan kronik hepatit B'li hastaların Hepatit D Virüs prevalans çalışmasında, Batı Anadolu'da \%14-16,5; Orta Anadolu'da \%28; Doğu ve Güneydoğu Anadolu'da \%33-38 olarak tespit ederken, 1980-90 yılları arasında \%31 olan HDV pozitiflik oranının 2000-2005 yılları arasında \%11'e kadar düştüğünü belirtmişlerdir [8]. 1998 yılından itibaren ulusal aşı takvimine eklenen Hepatit $B$ aşılanmasının, bu düşüşe etkisi olduğu açıkça görülmektedir.

2011 'de İstanbul'da yapılan çalışmada kronik HBV hastalarının \%4,4'ünde anti-HDV pozitif saptanmıştır [9]. Yine İstanbul'da yapılan bir çalışmada bu oran \%7 olarak bildirilmiştir [10].

Eskişehir'de saptanan \%0,9 HDV RNA pozitifliği ülkemiz geneliyle uyumlu olarak yıllar içerisinde azalma gösterdiği halde [11], 2016 yılı itibariyle Tokat'ta HDV-RNA oranının \%1,81 ile Eskişehir'den biraz daha yüksek oranda olduğu tespit edilmiştir.

Gürkan ve ark.[12] ile Niro ve ark. [13]'nın yaptığı çalışmalarda, HDV pozitif olan hastaların karaciğer enzim değerlerinin yüksek olduğu ve ALT-AST değerleri arasında anlamlı bir ilişki olduğu tespit edilmiştir. Yaptığımız çalışmada, bu çalışmalara benzer olarak, HDV-RNA pozitif olan hastalarda ALT-AST değerleri arasında istatiksel olarak anlamlı bir ilişki tespit edilmiştir.

2014 yılında Katar'da yapılan bir çalışmaya göre TTV oranı HBV 'de \%90,75 iken ilimizde bu değere yakın oranda TTV pozitifliği belirlenmiştir [14].

TTVile ilgiliyapılan diğer çalışmalarda, sağlıklıkan donörlerinde TTV-DNA pozitifliği Fransa' da \%2, A.B.D' de \%13, Gambiya'da \%83, Japonya' da \%17-93 olarak saptanmıştır. Ülkemizde kan donörlerinde yapılan çalışmalarda TTV-DNA pozitiflikleri ise İzmir'de \%51,6, İstanbul' da \%4,5 ve \%31, Bursa' da \%9,6, Ankara' da \%0,5 oranlarında bildirilmiştir. Ayrıca Türkiye' de hemodiyaliz hastalarında $\% 7,5$, fulminan hepatit olgularında $\% 80$, kronik B hepatitinde $\% 13,6$, kronik C hepatitinde $\% 7,2$, kriptojenik kronik aktif hepatitde \%38, kriptojenik karaciğer sirozunda \%20,5, talasemililerde \%79,6 gibi farklı oranlarda TTV-DNA pozitiflikleri saptanmıştır [15]. İlimizde ilk defa yapılan bu çalışmada Kronik Hepatit B' li hastalarda \% 96 ve sağlıklı bireylerde \% 95,5 olmak üzere benzer oranda TTV pozitifliği saptanmıştır. Bu oranların, ülkemizde ve dünyada yapılan diğer çalışmalarla karşılaştırıldığında, oldukça yüksek olduğu görülmektedir [15].

TTV Enfeksiyonu ile karaciğer enzimleri olan ALT ve AST arasındaki ilişkinin değerlendirildiği çalışmalarda önemli bir farkın olmadığı saptanmıştır $[3,16,17]$. Bu çalışmada da TTV pozitif örneklerin aynı dönemdeki karaciğer enzim değerleri arasında anlamlı bir farklılık saptanmamıştır (Tablo 2.). Tork Teno Virüs yıllar boyunca, mutlaka bir hastalık etkeni olması yönünde araştırılmıştır. Fakat TTV'nin, sağlıklı bireylerde karşılaşılan sonuçları değerlendirildiğinde oldukça yüksek oranlarda bulunduğu belirlenmiştir. Bu virüsün bireylerdeki varlığı daha geniş çapta araştırılmalı, hangi şartlarda hastalık yaptığı üzerinde durulup, bu konuda farklı incelemelerin yapılması zorunluluğu açığa çıkmaktadır.

HDV-RNA pozitif olan hastalarda ALT değerleri arasında istatiksel olarak anlamlı bir ilişki tespit edilirken, AST değerleri ile HDV-RNA pozitif olanlar arasında da anlamlı bir ilişki gözlenmiştir $(p<0,05)$.

TTV-DNA pozitif olan hastalar ile karaciğer fonksiyon testleri arasında anlamlı bir ilişki saptanmazken ( $p>0,05)$, TTV-DNA pozitif olan hastalar ile yaşları arasında istatiksel olarak anlamlı bir ilişki bulunmuştur $(p<0,05)$. Illeri yaş hastalardaki pozitifliğin genç yaş hastalara göre daha fazla olduğu saptanmıştır.

\section{Sonuç}

Tokat ilinin, HDV enfeksiyon oranı, Türkiye ortalamasının oldukça altında, dünya genelinde ise, çok düşük endemisite grubuna dahil bölgeler arasında olduğu görüldü. Tokat'ta ilk defa araştırılan TorkTenovirüs ise \%96 oranı ile dünya ve Türkiye ortalamasının oldukça üzerindedir. Kronik hepatit B enfeksiyonlu hasta grubunda araştırılan TorkTenovirüs ve hepatit deltavirüs enfeksiyonları arasında istatistiksel açıdan anlamlı bir ilişki saptanmamıştır. Tokat ilimizde kronik hepatit $B$ hastalarında, HDV sıklığı düşük saptanırken, Kronik hepatit B ile birlikte TTV sıklığının oldukça yüksek olduğu ve özellikle de ileri yaş hastalarda, genç hastalara göre daha fazla oranda gözlendiği saptanmıştır. TTV pozitifliğinin fazla olduğu belirlenmiştir.

\section{Çıkar çatışması / finansal destek beyanı}

Bu yazıdaki hiçbir yazarın herhangi bir çıkar çatışması yoktur. Yazının herhangi bir finansal desteği yoktur.

\section{Kaynaklar}

1. Hou J, Liu Z, Gu F. Epidemiology and Prevention of Hepatitis B Virus Infection. Int J Med Sci 2005; 2; 50-57.

2. Çelen MK. HDV enfeksiyonunun doğal seyri. Viral Hepatit 2009, Editörler: Balık, I, Tabak F. Viral Hepatitle Savaşım Derneği Express Matbaası 2009; 181-86.

3. Abdalla, N.M., Galal, A., Fatouh, A.A., Eid, K., Salama, E.E.E., Gomma, H.E. Transfusion Transmitted Virus (TTV) Infection in Polytransfused Egyptian Thalassemic Children. J of Med Sci 2006, 6; 833-37. 
4. De Paschale M, Manco MT, Belvisi L, Epidemiology of hepatitis D virus (HDV) infection in an urban area of Northern Italy. Infection 2012; 40: 485-91.

5. Ataei B, Yazdani MR, Kalantari H. Hepatitis D virüs infection in Isfahan, central Iran: prevalence and risk factors among chronic HBV infection cases. Hepatology 2011; 11; 269-72.

6. Mohammad AH, Ranjbar M, Tehrani AS. Seroprevalence of hepatitis $D$ virus and its risk factors in the west of Iran. J Microbiol Immunol Infect 2010; 43; 519-23.

7. Keshvari M. Seroepidemiology and clinical features of hepatitis delta among HBsAg carriers: a study from Hepatitis Clinic of Iranian Blood Transfusion Organization. Transfus Med 2014; 24: 411-17.

8. Değertekin H, Yalçın K, Yakut M, Yurdaydın C. Seropositivity for delta hepatitis in patients with chronic hepatitis B and liver cirrhosis in Turkey:a meta-analysis. Liver Int 2008; 28; 494-98.

9. İzmirli S, Çelik DG, Güngördü Z. Hepatit delta virüsü infeksiyonu seroprevalansı: retrospektif temelli seroepidemiyolojik bir değerlendirme. Flora 2011; 16; 120-26.

10. Yaşar K, Pehlivanoğlu F, Şengöz G. Sekiz aylık dönemde laboratuvarımızda saptanan hepatit $B$ ve hepatit $D$ seroprevelansı. Viral Hepatit Dergisi 2011;17; 22- 26.

11. Korkmaz P, Aykın N, Çevik FÇ, Güldüren HM, Alpay, Y. Seropositivity of Delta Hepatitis in HBsAg Positive Patients in Eskişehir Province Turkey. Viral Hepatitis J 2014; 20: 72-74.
12. Gürkan Y, Toyran A, Aksoy A, Coşkun FA, Çetin F. Ankara Numune Eğitim Araştırma Hastanesine 2010-2013 Yılları Arasında Başvuran Hastaların HBsag ve Anti-HDV Seroprevalanslarının Değerlendirilmesi. Viral Hepatit J 2013; 19; 148-151.

13. Niro GA, Smedile A, Ippolito AM et al Outcome of chronic delta hepatitis in Italy: A long-term cohort study. Journal of Hepatology 2010;53: 834-40.

14. AbuOdeh R, Al-Mawlawi N, Al-Qahtani AA. et al Detection and genotyping of torque teno virus (TTV) in healthy blood donors and patients infected with HBV or HCV in Qatar. J Med Virol 2015; Feb 9.

15. Kaya O, Akçam FZ. Yeni Hepatit Virusları. Sted 2005; 14: 179-81.

16. Heo WB, Lee NY, Jeong KY, Lee WK. TT Virus (TTV) İnfection in General Population, Chronic Liver Diseases, Hemodialysis, and Transfused Patients. Korean J Clin Microbiol 2006; 9:7-12.

17. De Oliveira JC, Nasser TF, Oda JM. et al Detection of TTV in peripheral blood cells from patients with altered ALT and AST levels.New Microbiol 2008; 31; 195-201. 